\title{
Hvor la jeg brillene mine nå, da?
}

Hukommelsen, som vi alle er så avhengig av, består av en rekke underavdelinger. Arbeidshukommelsen hjelper oss å holde en ny opplysning i minnet en kort stund, prosedyrehukommelsen hjelper oss til å skaffe oss en ny vane eller ferdighet og den semantiske hukommelsen hjelper oss til å kjenne igjen vanlige gjenstander rundt oss. En annen avdeling igjen sørger for at vi kjenner igjen de ideene og begrepene som omtales i radioens nyheter og at vi gjenkjenner stemmen til en kjent skuespiller.

Vi må være ytterst takknemlige for at hukommelsen ikke er én enkelt prosess eller ting - heldigvis bærer vi med oss en hel verden av såkalt implisitte ikke-bevisste minner. Disse behøver vi ikke å tenke på hele tiden - likevel er de vesentlige for våre evner til å utføre all slags nesten automatiske prosesser, som å sykle, spille favorittmelodien på pianoet eller kjenne igjen ansiktstrekkene til den gode vennen som nettopp kom innom.

En vanlig feiloppfatning er at våre hukommelsesinntrykk skapes ved en passiv gjengivelse av en tidligere opplevelse, omtrent som et filmopptak eller lydbåndregistrering av en scene i vårt liv. Vi lagrer ikke en filmliknende fremstilling av tidligere hendinger, men leter etter og fester oss ved meningen, sammenhengen og følelsene som disse hendingene skaffet oss. På en måte kan vi si at minnene må gjenskapes eller «gjenoppleves» inne i hjernen vår før vi kan huske det reelle innholdet.

Få mennesker har lært oss mer om hukommelsens irrganger enn epilepsipatienten Henry Molaison (1926-2008) fra New England. I sine mange pasientår ble han anonymisert via sine initialer HM. På grunn av en vanskelig håndterbar epilepsi ble han operert i 1953, 27 år gammel. Med bakgrunn i det man den gang visste om tinninglappen og epilepsi, fjernet man bilateralt de fremre halvpartene av de to hippocampi, tilstøtende deler av amygdala og deler av tinninglappenes neocortex. Riktignok bedret HMs allmenne medisinske tilstand seg ved at hans epilepsianfall ble redusert i styrke og hyppighet, men til behandlingsteamets store forskrekkelse ble han også rammet av en sterkt invalidiserende amnesi. Til tross for måneders daglig samvær husket han ikke navnet på noen av sine leger eller pleiere. Han visste ikke om det var gått kort eller lang tid siden han hadde spist, det samme gjaldt toalettbesøk.

Det ble heldigvis raskt klart at HMs amnesi ikke skyldtes en global cerebral skade. Hans allmenne intelligens, perseptuelle funksjoner, språkforståelse, språkproduksjon og en rekke kunnskaper og ferdigheter var intakte. Evnen til å gjengi en ordstreng var utmerket når den ble testet etter få sekunder. Men - når ordene skulle gjengis etter en kort pause, var resultatet katastrofalt dårlig.

HMs sykdomsbilde ble den første klare evidens for at strukturer i den mediale delen av tinninglappen spiller en viktig rolle for hukommelsen.

Søket etter en dyremodell startet umiddelbart, men det tok mange år før en plausibel modell ble rapportert. Løsningen kom da John O'Keefe og medarbeidere i 1971 rapporterte resultatene fra en studie på rotter som kunne bevege seg fritt $\mathrm{i}$ en innhegning med elektroder implantert i hippocampus og nærliggende strukturer. Mens andre neokortikale hjernebarkceller reagerte på bestemte attributter hos objektene, slik som kontur, farge eller bevegelse, reagerte hippocampuscellene på dyrets posisjon $i$ rommet, uavhengig av dyrets egen orientering. Derfor kalte O'Keefe disse cellene for «place cells». I 1978 presenterte O'Keefe og Lynn Nadel en viktig teori som pekte på at et samarbeid mellom et stort antall slike «plassceller» kunne danne et kognitivt kart som dyret kunne bruke til å orientere seg i forhold til de mange romlige (spatiale) stimuli i omgivelsene i sin søken etter mat, rede og makker og for å unngå fiender. Denne «cognitive map theory» er blitt en viktig ledesnor i moderne hukommelsesforskning.

Årets vinnere av Anders Jahres pris for medisinsk forskning er professorene May-Britt og Edvard I. Moser fra Kavli-instituttet for systemnevrovitenskap/Senter for hukommelsesbiologi ved Norges teknisk-naturvitenskapelige universitet. De har arbeidet i laboratoriet til John O'Keefe i London og sammen med Carol Barnes og Bruce McNaughton i laboratoriet til Lynn Nadel i Tucson, Arizona. Alle disse fire er veteraner fra «cognitive map theory». Fra sine utenlandsopphold har «the Mosers», som de ofte kalles, importert både viktige ideer og eksperimentalteknikker som de har omsatt til usedvanlig produktiv forskning i Trondheim.

Med videreutvikling av «place cell»-metoden fant de og deres medarbeidere først at koden for posisjonen sannsynligvis ikke blir dannet i selve hippocampus, men i et naboområde. Med tanke på resultatene til Santiago Ramón y Cajal (1852-1934) og Theodor W. Blackstad (1925-2003) var det naturlig å lete i area entorhinalis. Ganske riktig, her viste aktivitetsmønsteret at det ble dannet et kart over dyrets omgivelser som så blir sendt videre til hippocampus. Og ikke bare det - dette kartet $\mathrm{i}$ area entorhinalis har de mest uventede egenskaper! Cellene kalles gitterceller, og danner, i motsetning til vanlige geodetiske kart, multiplikative kart der et sted i periferien blir representert på flere steder i kartet og attpåtil i en triangulær fasong. Skulle vi lage et tilsvarende turistkart, måtte Kikut ikke bare rage opp som én enkelt kolle, men som et sett av Kikut-er hvor siktlinjene fra én til den neste Kikut-toppen danner 60 grader med hverandre.

Her skal nok mange skarpe hjerner få bryne seg før alle detaljer er forstått. Jeg ønsker prisvinnerne hjertelig til lykke - og ser frem til nye oppdagelser om hukommelsens mangfoldige substrater!

\section{Per Oskar Andersen}

Sverrestien 27

Blommenholm 